\section{HÔPITAL LA CHARITÉ, PARIS.}

REMARKS ON THE TREATMENT OF PNEUMONIA. (By Professor Germain Sḱe.)

IN a clinical lecture recently delivered at this hospital, Professor Sée made some valuable remarks on the above subject. He divided the methods of treatment into four1. Bouillaud's "jugulating" system (large bleedings). 2. The expectant method. 3. Cardiac medicines: tartar emetic in large doses, digitalis, veratrine (these should not be confounded with the antiphlogistic, which would include bleeding, nor with antipyretics, all of which do not act on the heart). 4. The English method of employing alcohol as a refrigerant and antipyretic, which was introduced into France by Professor Béhier. Lastly, he alluded to the method of treating symptoms : opium against cerebro-spinal manifestations ; large blisters, which brought on cystitis ; small blisters, to relieve pain.

Professor Sée, insisting on the method of expectancy, made some important remarks on its value, the significance of statistics, critical days, and the appearance of labial herpes. Dr. Grandmotet, a disciple of Teissier and a homcopath, had published a thesis crowded with cases cured by homoopathy. Valleix refuted the thesis, and showed that without any treatment at all cases of pneumonia recovered as well as with homœopathy; therefore, pneumonia was cured without any treatment.

There were, however, pneumonia and pleuro-pneumonia. First, there was the important question of age. Barthez and Legendre had established that all children from two to four invariably recovered without treatment, and Professor Sée, during his stay at the Hôpital des Enfants, had not seen one case of pneumonia end in death under the expectant treatment. In such cases bleeding and tartar enetic were dreadfully mischievous.

As to statistics, the following had been given in respect of the rate of mortality:-Bleeding, 20 per cent.; tartar emetic, 12 per cent.; digitaline and veratrine, about 9 per cent.; alcohol, 5 per cent. (Hughes Bennett); expectancy, 13 per cent. (German statistics.) But the truth was that figures, when drawn up without reference to the age of patients, were terribly misleading. In children, the mortality was 0 ; in adults, after fifty years, 50 per cent.

Again the age of the disease should be taken into account. Bouillaud pretended that by bleeding he "jugulated" pneumonia; and Cochère, of Berne, that he did the same with veratria. They were both right as to the first day, but not so as to the third. And here the study of critical days, so much insisted upon by Hippocrates, was most valuable. During the first day the thermometer showed $40^{\circ} \mathrm{C}$. ( $\left(104^{\circ} \mathrm{F}.\right)$, and as much during the three following days. On the morning of the fifth day there was a fall to $39^{\circ}$ C. $(102 \cdot 2 \mathrm{~F}$.$) , and the disease might be considered to be$ "jugulated"; but on the evening of the same day the temperature would rise to $40^{\circ} \mathrm{C}$. $\left(104^{\circ} \mathrm{F}\right.$ ), increase to $41^{\circ} \mathrm{C}$. (105.8 F.) on the sixth day, whilst on the seventh, which was really the critical day, defervescence began. Figures had shown that out of $\mathbf{2 2 6}$ cases, 33 recoveries took place on the fifth day (these had really been jugulated), 51 on the seventh, and 132 on the ninth.

What was the explanation of this crisis? Neither a philosophical one nor one founded on the exit of an illhumour, as had been formerly supposed, but a physiological one-the law of regeneration of tissue. During the course of pneumonia, the patient's heat was $40^{\circ} \mathrm{C}$. (104. F.), and consequently the blood clotted easily, fibrin formed in excess, and the urine presented an excessive quantity of urea, the temperature of the patient being at the greatest height. Only a little uric acid could be found in the urine, whilst the chlorides were altogether absent (a good test for distinguishing pneumonia from typhoid fever). On the critical day all these symptoms disappeared, the chlorides came back, and the urine was full of urates and uric acid.

Professor Sée concluded his remarks on expectancy by referring t $\Theta$ herpes labialis. This was not a critical phenomenon, since it appeared as early as the third day, but it was really a favourable sign. Out of 145 cases of pneumonia in which herpes had appeared, there were 123 cures, which took place definitively on the fifth or seventh day. Generally pneumonic sufferers with herpes died only in the proportion of 9 per cent., and those without in the proportion of 29 per cent. In the aged herpes seldom appeared: 75 per cent. with herpes recovered, and only 25 per cent. without herpes. In youth namely, a favourable time of age, herpes might be considered as almost a certain sign of speedy recovery.

\section{Aftrovical Socretites.}

\section{ROYAL MEDICAL AND CHIRURGICAL SOCIETY.} TUESDAY, APRIL 8TH, 1873.

Dr. C. J. B. Williays, F.R.S., Presidmat, in the Chair.

\section{ON THE ELEVATED HEALTH RESORTS OF SOUTHERN HEMI-} SPHERES, WITH SPECIAL REFERENCE TO SOUTH AFRICA.

$$
\text { BY E. SYMES THOMPSON, M.D., F.R.C.P., }
$$

PHYSICIAN TO THE HOSPITAL FOR CONSUMPTION, BROMPTON.

THe author observes that, whereas works on special health-resorts suited to the very wealthy and very delicate are almost numberless, there is a need for more general information about those less accessible resorts which, in these days of facile locomotion, are within the reach of persons of moderate means.

The profession, and the better-informed portions of the public, realise that chronic chest disease, or a tendency thereto, is not to be combated by a winter or two spent in a sunny health-resort; and that what is needed is a prolonged sojourn in a climate and under circumstances diverse from those in which the disease originated. They therefore manifest increasing readiness to advise the sufferer to undertake a long voyage, and stay several months or years in a well-selected climate.

The author, having had peculiarly favourable opportunities for gaining information about the Australian and South African colonies, trusts that his observations may not be without value to the Society.

The climates are classified, not according to latitude and elevation (Dr. Hermann Weber), but according to elevation and observed mean annual temperature. Isothermal lines are shown by a map to pass through countries in the Southern hemisphere in a very different and much more northerly position than do the isothermal lines corresponding to them in the Northern hemisphere.

Statistics of mean annual observations are misleading as criterions of actual temperature and rainfall, for thus places very dissimilar are grouped together-e.g., Lisbon and St. Helena, in which case the winter temperature of the former is $12^{\circ}$ colder, and summer $11^{\circ}$ hotter, than in the latter; while a place may have a dry climate and a heavy rainfall-e.g., the Karnatic, -and vice versâ.

Again, in the same district, the physical geography of the country may lead to vast diversity in forming a sound opinion of the climate; so it is needful to study each place in detail, although the isothermal lines are of service for general indications. So also with regard to latitude, for we must remember that for each parallel of latitude a lower elevation is sufficient for securing immunity from phthisis than in the corresponding parallel of the Northern hemisphere.

After touching upon the difficulty of deciding between the claims of the various European health resorts, some details are given as to the facilities and advantages of seavoyages, the superiority of the sea-voyage to India over the Suez route, and of the passage round the Cape of Good Hope over that round Cape Horn.

The first group of health resorts described is that of the Cape.

Cape Town (lat. $34^{\circ} \mathrm{S}$.) itself lies low; it is too hot, and subject to violent south-west winds; but Wynberg, reached by railway nine miles off, is healthy.

Graham's Town (1800 feet elevation) is healthy and somewhat cooler than Pieter Maritzburg, the capital of Natal. It bears the same climatic relation to Port Elizabeth as Maritzburg does to Port D'Urban.

Natal (lat. $28^{\circ}$ to $32^{\circ}$ S.) has low coast-lands almost subtropical in character, but the land rises in steps or plateaux. Maritzburg, its chief town, fifty miles from the coast, has an elevation of 2000 feet, and the land rises immediately behind to a height of 3800 feet. The prevailing moisture- 